DOI: https://doi.org/10.24127/ajpm.v9i3.2909

\title{
PENGEMBANGAN LEMBAR KERJA PESERTA DIDIK BERBASIS HIGHER ORDER THINKING SKILLS (HOTS) MENGGUNAKAN KONTEKS LINGKUNGAN
}

\author{
Rita Pramujiyanti Khotimah ${ }^{1}$, Meilina Cahya Prima Sari ${ }^{2}$
}

1,2 Pendidikan Matematika, Universitas Muhammadiyah Surakarta, Surakarta, Indonesia

$$
\text { E-mail: } \quad \frac{\text { rpramujiyanti@ums.ac.id }^{1)}}{\text { meilinaprima@gamil.com }^{2)}}
$$

Received 04 July 2020; Received in revised form 13 September 2020; Accepted 26 September 2020

\begin{abstract}
Abstrak
Penelitian ini bertujuan untuk 1) mengembangkan lembar kerja peserta didik (LKPD) berbasis Higher Order Thinking Skills (HOTS) pada materi sistem persamaan linear dua variabel menggunakan konteks lingkungan, 2) menguji kevalidan dan kepraktisan dari LKPD berbasis HOTS yang dikembangkan. Penelitian ini merupakan penelitian research and development dengan model pengembangan Plomp yang terdiri dari tiga fase, yaitu investigasi awal, pengembangan atau prototipe, dan penilaian. Penelitian ini hanya dilakukan hingga fase pengembangan atau prototipe. Fase investigasi awal telah dilakukan sebelumnya sebagai dasar pengembangan lembar kerja peserta didik. Fase pengembangan atau prototipe terdiri dari kegiatan mendesain rancangan awal lembar kerja, kemudian melakukan penilaian lembar kerja melalui kegiatan self evaluation, expert review evaluation, one-to-one evaluation dan small group evaluation. Teknik pengumpulan data yang digunakan adalah wawancara dan angket. Proses analis data hasil wawancara dilakukan dengan analisis deskriptif, sedangkan hasil angket kevalidan dan kepraktisan dianalisis secara deskriptif kualitatif dan kuantitatif. Hasil dari uji kevalidan menunjukkan bahwa LKPD berbasis HOTS memenuhi kriteria kevalidan dengan skor 3,385. Hasil dari uji kepraktisan menunjukkan bahwa LKPD berbasis HOTS memenuhi kriteria kepraktisan dengan skor 3,288. Berdasarkan hasil kevalidan dan kepraktisan dapat disimpulkan bahwa LKPD berbasis HOTS pada materi SPLDV menggunakan konteks lingkungan layak digunakan dalam pembelajaran.
\end{abstract}

Kata kunci: HOTS; konteks lingkungan; LKPD; SPLDV.

\begin{abstract}
This study aims to 1) develop student worksheets based on higher order thinking skills in systems of linear equation with two variable using envionmental context, and 2) test the validity and the practicality of students worksheet based on HOTS. This research is research and development study with a Plomp development model, consisting of three phases namely, prelimenary investigation phase, development or prototype phase, and assessment phase. This research is only carried out until development or prototype phase. Prelimenary investigation phase has been carried out before as a basis for development of students' worksheets. Development phase or prototype consists of designing the initial worksheet, then evaluating the worksheet through self evaluation, expert review evaluation, one-to-one evaluation and small group evaluation. Data collection techniques used were interviews and questionnaires. Data analysis process of interview results was carried out with descriptive analysis, while the results of validity and practicality questionnaire were analyzed descriptively qualitatively and quantitatively. Results of validity test showed that student worksheets based on HOTS met validity criteria with a score of 3.385. Results of practicality test showed that student worksheets based on HOTS met practicality criteria with a score of 3.288. Based on the validity and the practicality that has been obtained, it can be concluded that the student worksheet based on HOTS in systems of linear equation with two variables using environmental context is appropriate for use in learning.
\end{abstract}

Keywords: Environmental Context; HOTS ; Linear Equation Systems; Student Worksheets. 
DOI: https://doi.org/10.24127/ajpm.v9i3.2909

\section{PENDAHULUAN}

Higher Order Thinking Skills (HOTS) adalah salah satu keterampilan yang diperlukan dalam abad 21 yang mengarahkan siswa untuk berpikir kritis dan kreatif. Konsep berpikir secara HOTS relevan dengan tuntutan pendidikan abad 21 karena mengarahkan siswa untuk meningkatkan keterampilan akademik dan keterampilan sosial mereka dengan membiasakan diri untuk berbagi informasi, mengorganisasikan ide, mengekspresikan pendapat, atau pun menciptakan projek (Pratama \& Retnawati, 2018; Alismail \& McGuire, 2015). Menurut Liu, X. (2010) apabila keterampilan berpikir tingkat tinggi (HOTS) dikaitkan dengan revisi Taksonomi Bloom yang dikemukakan oleh Anderson \& Krathwohl (2010), maka HOTS pada dimensi kognitif meliputi proses menganalisis (analyzing), mengevaluasi (evaluating), dan mencipta (creating).

Masalah berbasis Higher Order Thinking Skills (HOTS) sering digunakan dalam penilaian internasional, salah satunya yaitu pada penilaian PISA (Programme for International Student Assessment) untuk mengukur kemampuan literasi matematika, sains, dan membaca bagi siswa berusia lima belas tahun. Beradasrkan hasil tes tiga tahunan yang dilakukan oleh PISA, skor literasi matematika siswa Indonesia pada PISA tahun 2018 adalah 379. Skor tersebut menunjukkan bahwa kemampuan literasi matematis siswa Indonesia masih berada di taraf low brenchmark sehingga menyebabkan posisi Indonesia berada pada peringkat 72 dari 78 negara peserta (OECD, PISA 2019).

Rendahnya kemampuan matematis siswa dalam penilaian internasional dapat sebabkan karena siswa belum terbiasa mengerjakan masalah berbasis HOTS (Alhassora, Abu, \& Abudullah, 2017). Hal lainnya dijelaskan oleh Jupri dan Drijvers (2016) bahwa siswa Indonesia masih kesulitan dalam penyelesaian soal cerita, penyusunan model matematika, dan mengidentifkasi suatu kesalahan pada persamaan matematika ataupun pada suatu diagram. Berdasarkan hasil wawancara dengan tiga guru matematika kelas VIII di SMP Negeri 2 Colomadu diperoleh informasi bahwa dalam proses pembelajaran guru masih menggunakan metode ceramah yang terkadang dikombinasikan dengan kegiatan diskusi. Sedangkan guru masih menggunakan masalah yang belum menuntut keterampilan berpikir tingkat tinggi, sehingga menyebabkan siswa masih kesulitan apabila dihadapkan dengan masalah kontekstual yang menuntut kemampuan menganalisis, mengevaluasi, dan mencipta. Informasi lain yang diperoleh yaitu, dalam pembelajaran matematika guru belum pernah menggunakan lembar kerja peserta didik (LKPD) baik dari penerbit maupun LKPD yang disusun mandiri oleh guru. Belum tersedianya LKPD dan jarangnya guru menggunakan soal yang menuntut kemampuan berpikir tingkat tinggi siswa menyebabkan kemampuan berpikir tingkat tinggi siswa SMP N 2 Colomadu masih rendah, dimana siswa masih kesulitan dihadapakan dengan masalah berbentuk penerapan soal cerita yang artinya kemampuan berpikir siswa kelas VIII di SMP N 2 Colamadu masih berada pada level 1-3. Belum tersedianya LKPD juga menyebabkan kemampuan menghadapi situasi secara kritis dan kreatif masih rendah. Hal ini bertentangn dengan fakta bahwa kemampuan berpikir kritis dan kreatif merupakan tolak ukur dari HOTS. 
Untuk mengatasi masalah tersebut guru dituntut untuk kreatif dalam penggunaan model, metode, dan bahan ajar yang dapat menumbuhkan HOTS siswa. Salah satu bahan ajar yang dapat dikombinasikan dengan masalah berbasis HOTS adalah Lembar Kerja Peserta Didik (LKPD). Lembar kerja peserta didik merupakan salah satu alat bantu belajar yang disiapkan oleh guru untuk siswa guna mendukung kegiatan pembalajaran lebih aktif dan meningkatkan antusiasme siswa dalam belajar (Verdina, Gani, \& Sulastri, 2018).

Pengembangan lembar kerja peserta didik dapat dikombinasikan dengan masalah berbasis HOTS karena melalui masalah berbasis HOTS, siswa dapat belajar mengembangkan keterampilannya dan dapat mengurangi kelemahan mereka (Tanujaya, 2016). Hal serupa dijelaskan oleh Musfiqi \& Jailani (2014) bahwa masalah berbasis HOTS memiliki karakteristik berupa kegiatan yang mengajak siswa untuk aktif dalam kegiatan pemecahan masalah secara kritis dan kreatif. Masalah HOTS dicirikan dengan suatu penilaian berbasis masalah nyata dalam kehidupan sehari-hari siswa. Salah satu masalah dalam kehidupan sehari-hari yang dapat digunakan dalam pengembangan LKPD berbasis HOTS adalah masalah lingkungan, seperti pemanasan global, pencemaran lingkungan, hingga hilangnya sumber daya alam.

Namun, guru masih jarang menggunakan masalah lingkungan sebagai bahan diskusi dalam pemebelajaran juga menyebabkan kemampuan siswa untuk berpikir secara kritis masih kurang. Habibi (2014) menjelaskan bahwa melalui masalah lingkungan, siswa dapat mengembangkan kompetensi matematis mereka, seperti menganalisis, merepresentasikan, memodelkan, dan menafsirkan data, sehingga siswa lebih kiritis terhadap fenomena alam, sosial, dan lainnya di sekitar mereka.

Berdasarkan beberapa penelitian tersebut maka dilakukakanlah penelitian dan pengembangan Lembar Kerja Peserta Didik (LKPD) berbasis Higher Order Thinking Skills (HOTS) pada materi Sistem Persamaan Linear Dua Variabel (SPDLV) menggunakan konteks lingkungan. Materi SPLDV dijadikan materi dalam pengembangan masalah HOTS karena pada materi sistem persamaa linear dua variabel terdapat dua jenis soal yang sering digunakan oleh guru, yaitu soal yang sudah dalam bentuk matematika dan soal dalam bentuk cerita. Siswa masih kesulitan dalam menganalisis masalah untuk menentukan informasi yang diketahui dan ditanyakan pada soal cerita. Oleh sebab itu, dikembangkanlah LKPD berbasis HOTS pada materi SPLDV menggunakan konteks lingkungan yang bertujuan untuk menghasilkan LKPD yang valid dan praktis sehingga layak digunakan dalam pembelejaran.

\section{METODE PENELITIAN}

Jenis penelitian ini adalah research and development dengan menggunakan model pengembangan Plomp. Model pengembangan Plomp (2013) terdiri dari tiga fase, yaitu fase investigasi awal (prelimenary investigation), fase pengembangan atau prototipe (development or prototyping phase), dan fase penilaian (assessment phase). Penelitian ini hanya dilakukan hingga fase pengembangan atau prototipe (development or prototyping phase) untuk mengembangan LKPD berbasis HOTS serta untuk menguji 
kevalidan dan kepraktisannya. Hal tersebut sejalan dengan penelitian yang dilakukan oleh Yusri, Nurmi, \& Delyana. (2019) yaitu dalam penelitiannya melakukan penelitian dan pengembangan LKPD hingga fase pengembangan bertujuan untuk mengetahui kevalidan dan kepraktisan produk, dimana produk yang dikembangkannya dapat dinyatakan valid dan praktis sehingga dapat digunakan dalam pembelejaran. Pengembangan LKPD berbasis HOTS pada materi SPLDV didasari pada hasil investigasi awal (prelimenary investigation) yang telah dilakukan sebelumnya.

Fase pengembangan atau prototipe terdiri dari kegiatan merancang rancangan awal lembar kerja peserta didik, kemudian dilakukan kegiatan evaluasi formatif terdiri dari self evaluation, expert review, one-toone evaluation, dan small group (Syaspasbandah, Syarifuddin, \& Jasrial, 2018). Penyusunan rancangan awal, meliputi perumusan tujuan pembelajaran, merancang LKPD berbasis HOTS, dan instrumen penilaian. Subjek pengembangan pada tahap self evaluation adalah peneliti sendiri, sedangkan pada tahap expert review subjek pengembangannya adalah para ahli yaitu satu dosen pendidikan matematika Universitas Muhammadiyah Surakarta dan dua orang guru matematika kelas VIII SMP Negeri 2 Colomadu. Subjek pengembangan pada tahap one-to-one evaluation adalah 2 siswa kelas VIII. Dua siswa yang menjadi subjek uji coba pada tahap one-to-one evaluation terdiri dari satu siswa yang memiliki kemampuan matematika baik, dan satu siswa yang memiliki kemampuan matematika rendah, sedangkan pada tahap small group subjek pengembangan adalah 6 siswa kelas VIII. Enam siswa yang menjadi subjek uji coba terdiri dari dua siswa yang berkemampuan matematika baik, dua berkemampuan matematika sedang, dan dua siswa berkemampuan matematika rendah. Hal serupa dilakukan Musfiqi \& Jailani (2014) dalam penelitian, yaitu melakukan uji keterbacaan pada sekelompok siswa berjumlah 6 orang untuk mengetahui kepraktisan dan kekurangan lembar kerja yang dikembangkannya.

Teknik pengumpulan data yang digunakan dalam penelitian: yaitu (1) wawancara, wawancara digunakan pada tahap one-to-one evaluation untuk memperoleh informasi mengenai kekurangan LKPD berbasis HOTS yang sedang dikembangkan dari segi tampilan, bahasa, dan langkah-langkah pengerjaan, dan pada tahap small group untuk mengetahui komentar siswa mengenai masalah yang mungkin dijumpai dalam menggunakan lembar kerja peserta didik; (2) angket, angket digunakan pada tahap expert review untuk mengetahui kevalidan mengenai LKPD berbasis HOTS yang sedang dikembangkan. Angket juga digunakan pada tahap small group untuk mengetahui kepraktisan lembar kerja peserta didik berdasarkan respon siswa.

Data hasil angket kevalidan dan kepraktisan dianalisis secara deskriptif kuantitatif dan kualitatif untuk memperoleh makna dari setiap skor yang diberikan dengan cara menentukan nilai rata-rata skor kemudian mengonversikannya ke dalam data kualitatif. Jenis angket yang digunakan adalah angket tertutup. Angket dinilai dengan menggunakan skala Likert dengan alternatif jawabannya yaitu, nilai $4=$ Sangat Setuju (ST), nilai $3=$ Setuju (3), nilai $2=$ Kurang Setuju (KS) dan nilai $1=$ Tidak Setuju (TS) 
(Arikunto, 2010: 285). Rumus untuk menentukan skor rata-rata kevalidan dan kepraktisan diadaptasi dari Arikunto. (2010) pada rumus (1).

$$
\bar{x}=\frac{\sum x}{N \times n}
$$

Keterangan:

$\bar{x}=$ Skor rata-rata

$\sum x=$ Jumlah skor

$N=$ Jumlah item pertanyaan

$n=$ Jumlah responden

Data kuantitatif berupa skor ratarata angket kevalidan dan kepraktisan kemudian dikonversi ke dalam data kualitatif menggunakan penilian skor standar dalam lima kategori yang diadaptasi dari Widoyoko (2010: 238) pada Tabel 1.

Tabel 1. Konversi data kuantitatif ke kualitatif.

\begin{tabular}{ccc}
\hline No & $\begin{array}{c}\text { Rentang } \\
\text { Skor }\end{array}$ & Kriteria \\
\hline 1 & $X>3,4$ & Sangat baik \\
2 & $2,8<X \leq 3,4$ & Baik \\
3 & $2,2<X \leq 2,8$ & Cukup \\
4 & $1,6<X \leq 2,2$ & Kurang \\
5 & $X \leq 1,6$ & Sangat \\
\hline
\end{tabular}

(Widoyoko, 2010: 238)

Keterangan:

$X \quad=$ Skor empiris

$\bar{X} \quad=$ Rerata ideal

$=\frac{1}{2}($ skor maksimum ideal + skor minumum ideal)

$s b_{i} \quad=$ Simpangan baku $=\frac{1}{6}($ skor maksimum ideal - skor minumum ideal)

Skor maksimum ideal dan skor minimum ideal adalah skor tertinggi dan terendah yang dapat diberikan oleh responden berdasarkan skala yang digunakan. Skor maksimum yang dapat diberikan oleh responden adalah 4, sedangkan skor minimum adalah 1 . Berdasarkan skor tersebut diperoleh kriteria kevalidan dan kepraktisan yang dapat dilihat pada Tabel 2.

Tabel 2. Hasil konversi skor ke dalam skala lima.

\begin{tabular}{|c|c|c|}
\hline No & $\begin{array}{l}\text { Rentang Skor } \\
\text { Kuantitatif }\end{array}$ & Kriteria \\
\hline 1 & $X>\bar{X}+1,8 \times s b_{i}$ & $\begin{array}{l}\text { Sangat } \\
\text { baik }\end{array}$ \\
\hline 2 & $\begin{array}{l}\bar{X}+0,6 \times s b_{i}< \\
X \leq \bar{X}+1,8 \times s b_{i}\end{array}$ & Baik \\
\hline 3 & $\begin{array}{l}\bar{X}-0,6 \times s b_{i}< \\
X \leq \bar{X}+0,6 \times s b_{i}\end{array}$ & Cukup \\
\hline 4 & $\begin{array}{l}\bar{X}-1,8 \times s b_{i}< \\
X \leq \bar{X}-0,6 \times s b_{i}\end{array}$ & Kurang \\
\hline 5 & $X \leq \bar{X}-1,8 \times s b_{i}$ & $\begin{array}{l}\text { Sangat } \\
\text { kurang }\end{array}$ \\
\hline \multicolumn{3}{|c|}{$\begin{array}{l}\text { Lembar kerja yang } \\
\text { dikembangkan dinyatakan layak ditinjau } \\
\text { dari aspek kevalidan dan kepraktisan } \\
\text { menurut Norsanty \& Chairani (2016) } \\
\text { jika hasil analisis angket kevalidan dan } \\
\text { respon siswa berada pada kategori baik } \\
\text { atau sangat baik. Hasil analisis } \\
\text { kevalidan dan kepraktisan yang tidak } \\
\text { berada pada kategori baik akan } \\
\text { dijadikan bahan pertimbangan untuk } \\
\text { melakukan revisi produk sebelum diuji } \\
\text { cobakan secara luas. }\end{array}$} \\
\hline
\end{tabular}

\section{HASIL DAN PEMBAHASAN}

Pengembangan Lembar Kerja Peserta Didik (LKPD) berbasis Higher Order Thinking Skills (HOTS) diawali dengan kegiatan mendesaian rancangan awal LKPD berbasis HOTS, kemudian melakukan serangkaian kegiatan, yaitu self evaluation, expert review, one-toone evaluation, dan small group. Hasil dari setiap proses pengembangan LKPD 
berbasis HOTS dijelaskan sebagai berikut.

1. Rancangan awal

Rancangan awal kerja peserta didik berbasis HOTS meliputi desain sampul lembar kerja, desain pembagaian submateri, desain tujuan kegiatan, desain petunjuk pengerjaan, pembuatan masalah, dan pembuatan langkahlangkah pengerjaan.

Desain sampul merupakan bagian utama dalam pengembangan bahan ajar cetak. Pembuatan sampul lembar kerja menggunakan Microsoft World 2007. Dalam sampul lembar kerja terdapat nama pengarang, identitas lembar kerja, materi pelajaran dan kelas. Desain sampul lembar kerja peserta didik dapat dilihat pada Gambar 1.

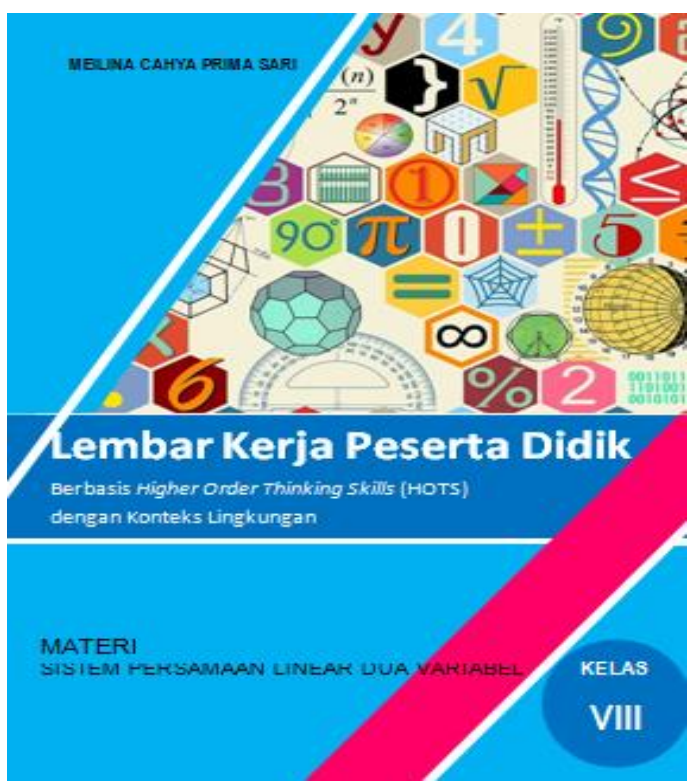

Gambar 1. Desain sampul lembar kerja peserta didik.

Dalam lembar kerja peserta didik berbasis HOTS pada materi sistem persamaan linear dua variabel (SPLDV), terdapat 4 sub materi sistem persamaan linear dua variabel, yaitu menemukan konsep persamaan linear dua variabel, menyelesaikan sistem persamaan linear dua variabel dengan metode grafik, menyelesaikan sistem persamaan linear dua variabel dengan metode substitusi, dan menyelesaikan sistem persamaan linear dua variabel dengan metode eliminasi. Masingmasing sub materi akan dipelajari dalam satu lembar kerja. Adapun desain pembagian sub materi dapat dilihat pada Gambar 2.

\section{LEMBAR KERJA PESERTA DDIK I}

MENEMUKAN KONSEP PERSAMAAN LINEAR DUA VARIABEL

Gambar 2. Desain sub materi lembar kerja peserta didik.

Indikator dan tujuan pembelajaran disusun sesuai dengan sub materi yang dipelajari pada setiap lembar kerja peserta didik. Desain tujuan kegiatan yang akan dicapai dapat dilihat pada Gambar 3.

\begin{tabular}{|c|c|}
\hline $\mathrm{KD} 3.5$ & $\begin{array}{l}\text { Menjelaskan sistem persamaan linear dua variabel dan } \\
\text { penyelesaiarnyayang dihubungkan denganmasalah kontekstual. }\end{array}$ \\
\hline $\mathrm{KD} 4.5$ & $\begin{array}{l}\text { Menyelesaikan masalahyang berkaitan dengan sistem persamaan } \\
\text { linear dua variabel. }\end{array}$ \\
\hline & $\begin{array}{l}1 \text { Menemukankonsep persamaan linear dua variabel melalui gra fik } \\
\text { persamaan garis berdasarkan masalah kontekstual. }\end{array}$ \\
\hline Indikator 3.5 .2 & 2 Menjelaskan definisi persamaan linear dua variabel berdasarkan \\
\hline & konsep yang telah ditemukan. \\
\hline Indikator 4.5 .1 & $\begin{array}{l}1 \text { Menyelesaikan masalah kontekstual menggunakan konsep } \\
\text { persamaan linear dua variabel. }\end{array}$ \\
\hline Tujuan 3.5.1 & $\begin{array}{l}\text { Melalui kegiatan pada LKPD siswa dapat menemukan konsep } \\
\text { persamaan linear dua variabel melalui gra fik persamaan garis } \\
\text { berdasarkan masalah kontekstual dengan tepat. }\end{array}$ \\
\hline Tujuan 3.5 .2 & $\begin{array}{l}\text { Melalui kegiatan pada LKPD siswa dapat menjelaskan definisi } \\
\text { persamaan linear dua variabel berdasarkan konsep yang telah } \\
\text { ditemukan dengan tepat. }\end{array}$ \\
\hline Tujuan 4.5.1 & $\begin{array}{l}\text { Melalui kegiatan pada LKPD siswa dapat menyelesaikanmasalah } \\
\text { kontekstual dengan menggunakan konsep persamaan linear dua } \\
\text { variabel dengan tepat dan benar. }\end{array}$ \\
\hline
\end{tabular}

Gambar 3. Tujuan kegiatan LKPD yang akan dicapai.

Selain itu, pada LKPD berbasis HOTS yang dikembangkan, diberi petunjuk pengerjaan yang bertujuan untuk mempermudah peserta didik dalam kegiatan pembelajaran dengan durasi waktu pengerjaan yang telah ditetapkan. Desain petunjuk pengerjaan dapat dilihat pada Gambar 4. 
DOI: https://doi.org/10.24127/ajpm.v9i3.2909

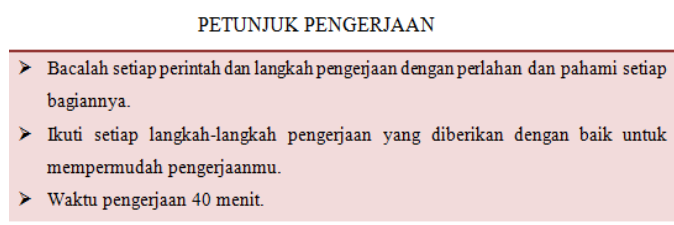

Gambar 4. Petunjuk Pengerjaan LKPD

Pengembangan LKPD berbasis HOTS menggunakan tiga level kemampuan kognitif berdasarkan revisi Taksonomi Bloom yang dikemukakan oleh Anderson \& Krathwohl (2010), yaitu kemampuan menganalisis (analyzing), mengevaluasi (evaluating) dan mencipta (creating). Terdapat dua jenis masalah yang digunakan dalam lembar kerja peserta didik. Masalah pertama adalah masalah pengantar yang digunakan untuk penemuan konsep sistem persamaan linear dua variabel (SPLDV). Masalah kedua adalah masalah berbasis Higher Order Thinking Skills (HOTS). Masalah berbasis HOTS digunakan agar siswa dapat menerapkan konsep yang telah mereka temukan untuk menyelesaikan masalah.

Masalah HOTS yang digunakan pada LKPD I adalah masalah dengan kemampuan menganalisis (C4). Berdasarkan masalah pada Gambar 5 siswa diminta untuk menganalisis data manakah yang menunjukkan suatu persamaan linear dua variabel dengan menerapkan konsep persamaan linear dua variabel yang telah mereka temukan.

Masalah HOTS yang digunakan pada LKPD II adalah masalah dengan kemampuan mengevaluasi (C5). Berdasarkan masalah pada Gambar 6 . siswa diminta untuk memeriksa kebenaran pernyataan dengan menggunakan konsep penyelesian sistem persamaan linear dua variabel dengan metode grafik.

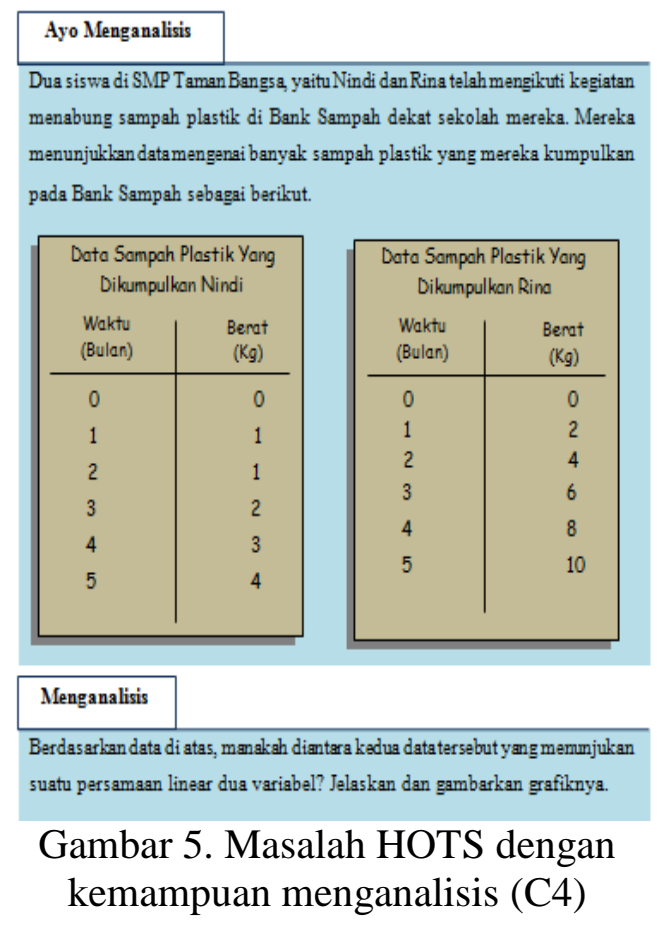

Ayo Memeriksa

Ahmad dan Andi mengikuti kegiatan pendakian untuk membersitkan lokasi pendakian dari sampah. Ahmad dan Andi mulai mendaki tetapi dengan lokasi awal yang berbeda. Ahmad mulai mendaki dari jalan setapak dengan kecepatan pendakian adalah $5 \mathrm{~km}$ per jam, sedangkan Andi mulai mendaki $3 \mathrm{~km}$ di depan jalan setapak dengan kecepatan pendakian adalah $3 \mathrm{~lm}$ per jam.

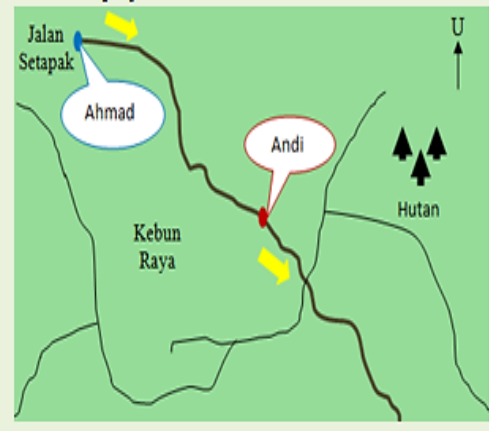

Memeriksa

Andi berkata bahwa setelah satu jam perjalanan, mereka berdua akan bertemu pada lokasi yang sama. Apakah penyyataan Andi benar? Tuliskan dan gambarkan grafik persamaan limear dua variabllnya untuk memeriksa penyataan Andi.

Gambar 6. Masalah HOTS dengan kemampuan mengevaluasi (C5)

Masalah HOTS yang digunakan pada LKPD III adalah masalah dengan kemampuan mencipta (C6) dan mengevaluasi (C5). Berdasarkan masalah pada Gambar 7. siswa diminta untuk memperkirakan banyaknya siswa 
yang memilih masing-masing cara untuk menyelematkan bumi dari global warming. Selanjutnya siswa diminta menguji kebenaran perkiraan mereka dengan menggunakan konsep penyelesaian sistem persmaan linear dua variabel dengan metode substitusi.

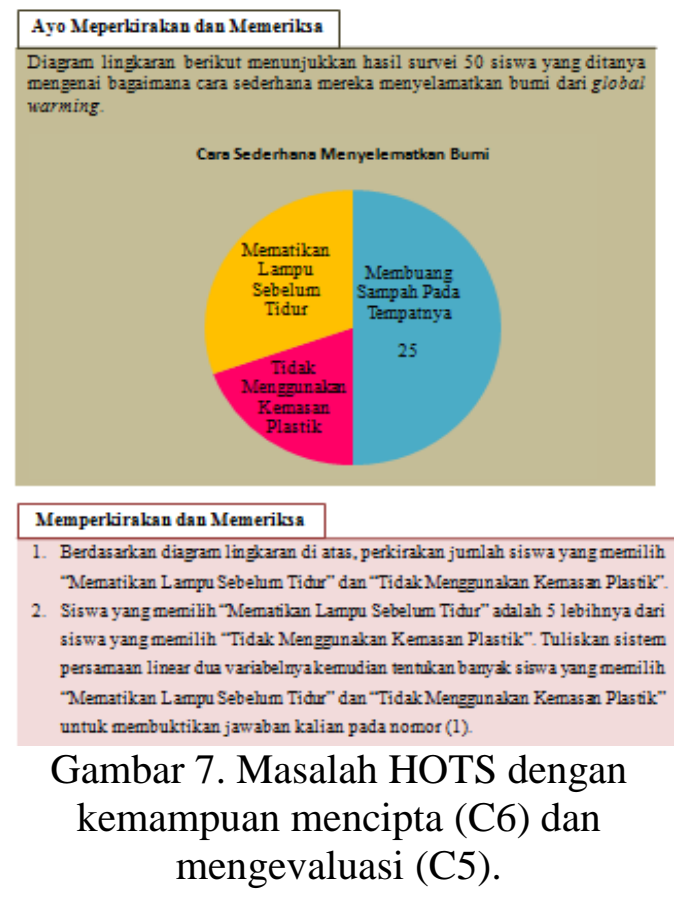

Masalah HOTS yang digunakan pada LKPD IV adalah masalah dengan kemampuan menganalisis (C4) dan mencipta (C6). Berdasarkan masalah pada Gambar 8 siswa diminta untuk menganalisis produk manakah yang paling banyak membutuhkan plastik kopi dan membuat persamaan pendapatan dari kegiatan penjualan produk dompet dengan menggunakan metode eliminasi.

Pada lembar kerja peserta didik berbasis HOTS diberikan langkahlangkah pengerjaan yang disusun secara sistematis runtut untuk memudahkan siswa menyelesaiakn masalah. Langkah-langkah pengerjaan pada Gambar 9 disusun dengan memperhatikan kepraktisan penggunaan lembar kerja bagi siswa.

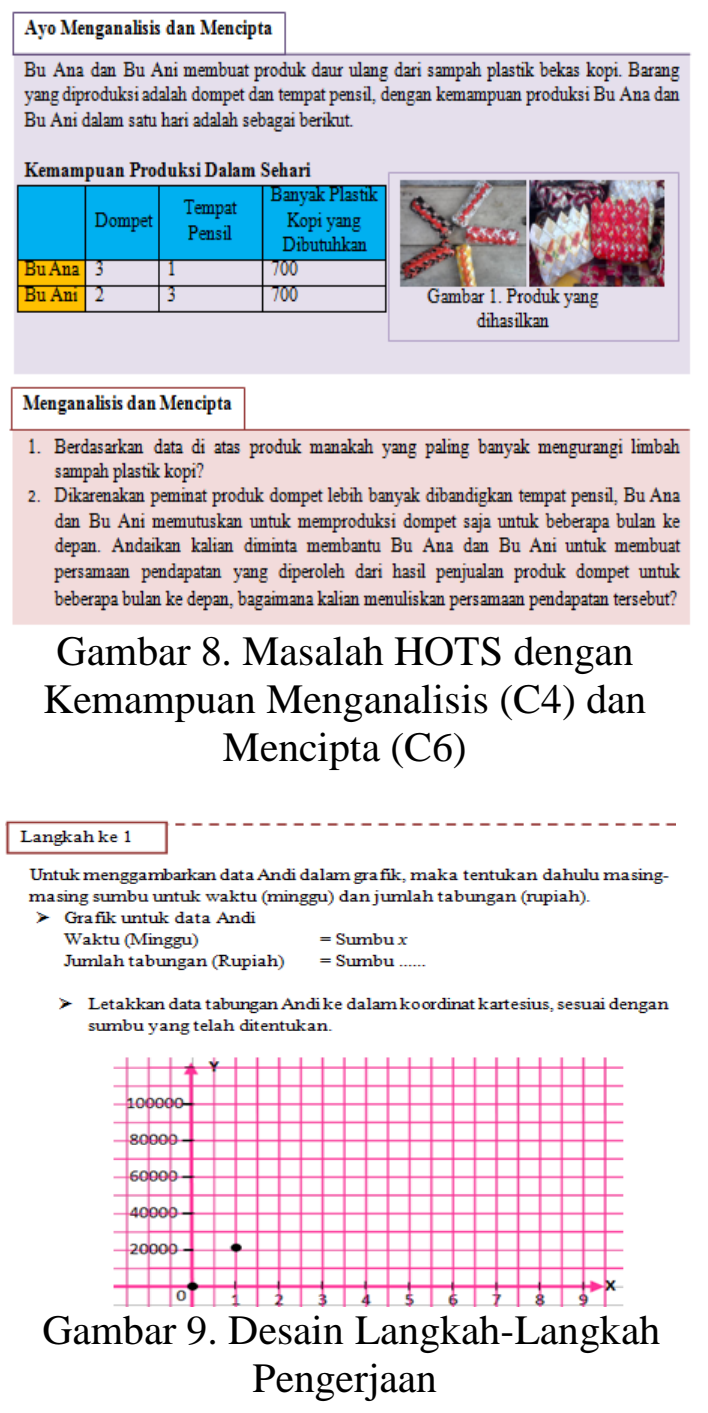

Setelah mendesaian Lembar Kerja Peserta Didik (LKPD) berbasis Higher Order Thinking Skills (HOTS), langkah selanjutnya yaitu, menyusun pedoman penskoran. Pedoman penskoran disusun untuk memudahkan guru dalam proses penilaian. Pedoman penskoran lembar kerja tersebut terdiri dari kemungkinan jawaban yang muncul dari setiap langkah yang diberikan, pemberian skor pada setiap butir berdasarkan kemungkinan jawaban dan setiap petunjuk, jumlah skor maksimal yang diperoleh siswa, dan rumus untuk menghitung skor siswa. 
DOI: https://doi.org/10.24127/ajpm.v9i3.2909

\section{Hasil Self Evaluation}

Hasil rancangan awal dari Lembar Kerja Peserta Didik (LKPD) berbasis Higher Order Thinking Skills (HOTS) yang telah didesain kemudian diperiksa kembali. Pemerikasaan kembali dilakukan dengan tujuan untuk mengetahui kelengkapan profil lembar kerja peserta didik, alternatif jawaban, dan pedoman penskoran. Pemeriksaan kembali perlu dilakukan dengan saikbaiknya. Berdasarkan hasil evaluasi yang telah dilakukan, ditemukan beberapa kesalahan pada tata tulis, sehingga perlu dilakukan perbaikan terhadap rancangan awal LKPD berbasis HOTS. Setelah selesai, hasil perbaikan rancangan awal LKPD berbasis HOTS disebut Prototipe I.

\section{Hasil Expert Review}

Pada tahap ini dilakukan penilaian oleh ahli (expert) terhadap Prototipe I yang telah didesian untuk diperiksa kelayakannya dari segi kevalidan dan meminta saran tertulis tentang lembar kerja yang sedang dikembangkan. Saran yang diberikan oleh ahli kemudian digunakan untuk melakukan perbaikan terhadap Prototipe I. Validasi Prototipe I dilakukan oleh 3 ahli (expert) yaitu, satu ahli media dan dua ahli materi yaitu guru matematika kelas VIII SMP Negeri 2 Colomadu. Masing-masing ahli (expert) memperoleh seperangkat Lembar Kerja Peserta Didik (LKPD) berbasis HOTS dan lembar validasi. Hasil dari pengisian angket kevalidan dapat dilihat pada Tabel 3 .

Tabel 3. Hasil angket kevalidan LKPD.

\begin{tabular}{ccccc}
\hline No & Aspek & Jumlah Item & Rerata & Kriteria \\
\hline 1 & Kompetensi & 4 & 3,333 & Baik \\
2 & Struktur & 1 & 3,333 & Baik \\
3 & Konstruksi & 4 & 3,167 & Baik \\
4 & Teknis & 5 & 3,2 & Baik \\
5 & Manfaat bagi pembelajaran & 2 & 4 & Sangat Baik \\
6 & Penggunaan stimulus HOTS & 2 & 3,333 & Baik \\
7 & Karakteristik masalah & 6 & 3,333 & Baik \\
& berbasis HOTS & & & Baik \\
& Kesimpulan & $\mathbf{2 4}$ & $\mathbf{3 , 3 8 5}$ & \\
\hline
\end{tabular}

Berdasarkan analisis pada angket kevalidan pada Tabel 3, diperoleh ratarata skor angket adalah 3,385 dengan kriteria baik, artinya LKPD berbasis HOTS yang dikembangkan dinyatakan valid berdasarkan ketercapian indikator LKPD dan HOTS. Terdapat beberapa catatan perbaikan yang diberikan ahli (expert) mengenai LKPD berbasis HOTS, adapun catatan perbaikan yang diberikan oleh expert, antara lain:
a) Perbaikan redaksi pada masalah berbasis HOTS
Pada Gambar 10, ahli (expert) memberi catatan agar tidak

memunculkan angka dalam diagram lingkaran. Hal tersebut dimaksdukan untuk menumbuhkan kemampuan siswa dalam menganalisis masalah. Ahli (expert) menyarankan untuk mengganti angka dengan menggunakan simbol lain yang menunjukkan banyaknya siswa yang memilih "Membuang Sampah Pada Tempatnya" adalah setengahnya dari 50 siswa yang mengikuti survey. Hasil perbaikan setelah revisi dapat dilihat pada Gambar 11. 


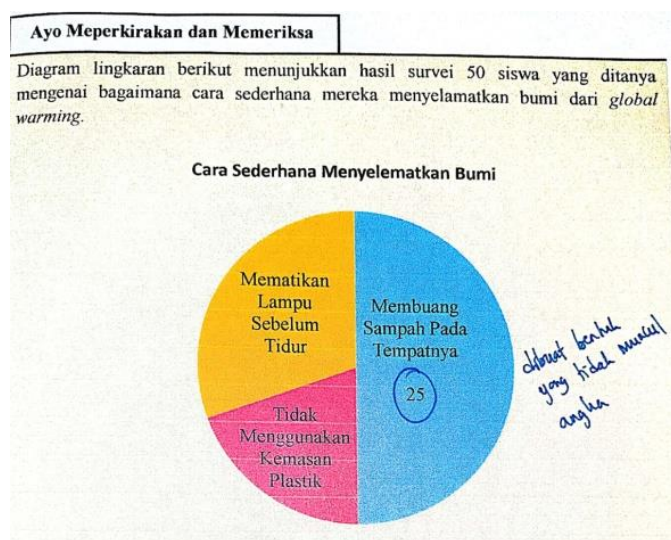

Gambar 10. Redaksi Kalimat Sebelum Direvisi

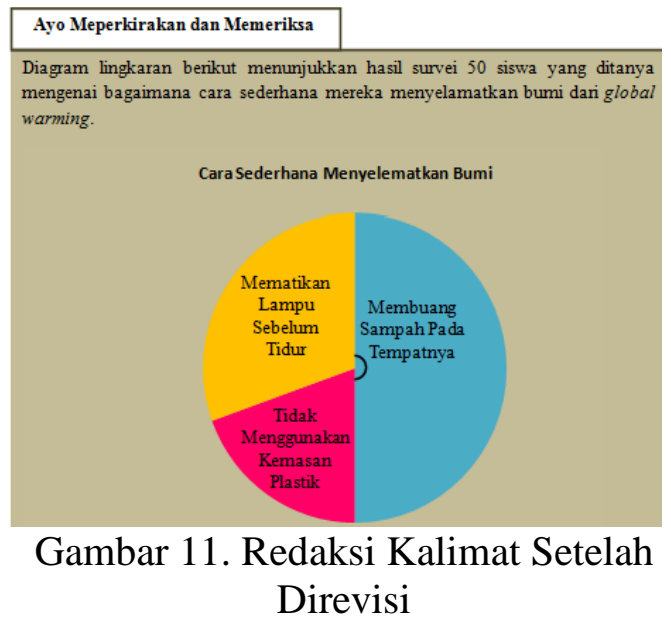

b) Perbaikan langkah pengerjaan dalam LKPD berbasis HOTS

Perbaikan langkah dalam menyamakan koefisien pada lembar kerja peserta didik mengenai penyelesaian SPLDV dengan menggunakan metode eliminasi dimaksudkan agar langkah-langkah yang ada dalam LKPD sesuai dengan langkah-langkah yang dijelaskan oleh guru. Gambar 12 menunjukkan langkah pada LKPD sebelum direvisi dan Gambar 13 setelah direvisi.

Berdasarkan penilaian dan saran yang diberikan para ahli (expert) pada Lembar Kerja Peserta Didik (LKPD) berbasis Higher Order Thinking Skills (HOTS), maka LKPD dinyatakan layak diujikan setelah dilakukan serangkaian perbaikan berdasarkan saran yang diberikan oleh ahli (expert).

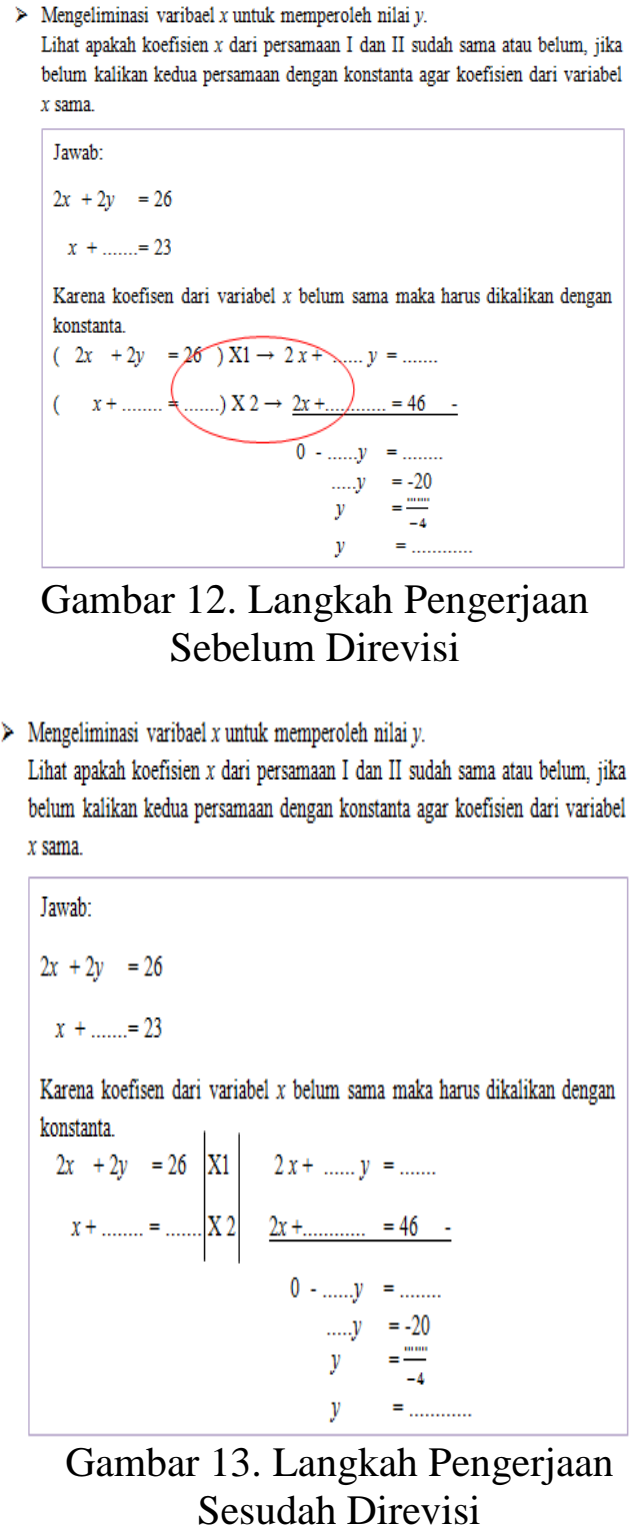

Gambar 12. Langkah Pengerjaan Sebelum Direvisi

Gambar 13. Langkah Pengerjaan Sesudah Direvisi

\section{Hasil One-to-one Evaluation}

Kegiatan pada tahap one-to-one dilakukan secara paralel setelah kegiatan expert review selesai. Setelah peneliti memberikan LKPD berbasis HOTS kepada para ahli untuk dinilai kevalidannya, selanjutnya peneliti memberikan LKPD berbasis HOTS kepada dua siswa kelas VIII SMP Negeri 2 Colomadu untuk mengetahui kekurangan Prototipe I dari segi 
DOI: https://doi.org/10.24127/ajpm.v9i3.2909

tampilan, bahasa, dan langkah-langkah pengerjaan melalui kegiatan wawancara.

Berdasarkan hasil wawancara dengan kedua siswa, diperoleh informasi bahwa masih terdapat beberapa kesulitan pemahaman pada langkah kerja dalam LKPD berbasis HOTS, sehingga peneliti melakukan perbaikan sebagai berikut. Gambar 14 merupakan langkah pengerjaan LKPD sebelum direvisi dan Gambar 15 merupakan langkah pengerjaan LKPD setelah direvisi.

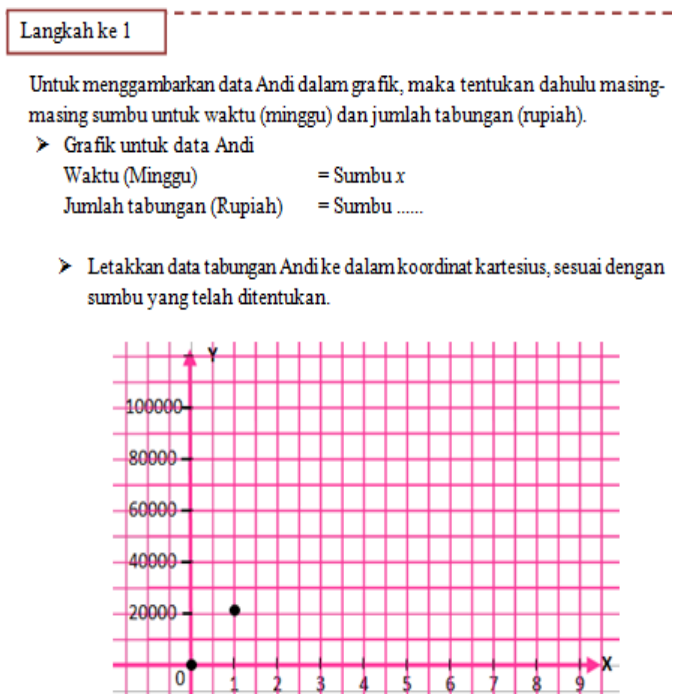

Gambar 14. Langkah Pengerjaan LKPD Sebelum Direvisi

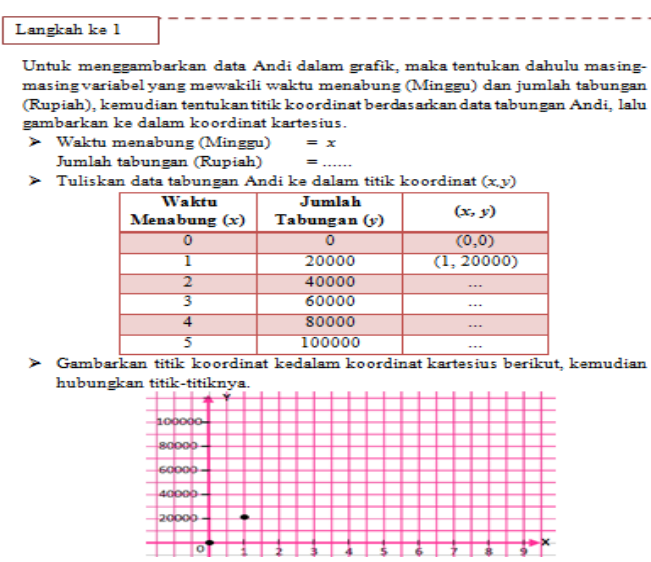

Gambar 15. Langkah Pengerjaan LKPD Setelah Direvisi
Setelah dilakukan revisi berdasarkan saran yang diberikan ahli (expert) dan komentar siswa, maka lembar kerja peserta didik berbasis Higher Order Thinking Skills (HOTS) dinyatakan valid dengan skor 3,385. Lembar kerja yang valid ini kemudian disebut Prototipe II yang dapat diujikan terbatas pada tahap small group.

\section{Hasil Small Group}

Prototipe II berupa lembar kerja peserta didik berbasis HOTS yang telah valid untuk kemudian diujikan terbatas kepada 6 siswa kelas VIII di SMP Negeri 2 Colomadu. Tujuan dari tahap uji terbatas (small group) ini adalah untuk mengetahui tingkat pemahaman siswa terhadap LKPD berbasis HOTS melalui uji keterbacaan. Siswa diminta untuk mencermati empat sub materi pada LKPD berbasis HOTS yang diberikan kemudian siswa diminta untuk mengisi angket kepraktisan untuk menilai apakah LKPD berbasis HOTS yang dikembangkan memenuhi kriteria kepraktisan. Hasil dari pengisian angket menjadi dasar untuk melakukan perbaikan atau tidak selanjutnya. Hasil pengisian angket kepraktisan oleh 6 siswa kelas VIII SMP Negeri 2 Colomadu dapat dilihat pada Tabel 4.

Berdasarkan analisis pada angket kepraktisan yang diisi oleh siswa, diperoleh rata-rata skor angket adalah 3,288 dengan kriteria baik, artinya LKPD berbasis HOTS yang dikembangkan dapat dinyatakan praktis berdasarkan ketercapian indikator kepraktisan lembar kerja peserta didik.

Setelah siswa mengisi angket siswa, selanjutnya dilakukan wawancara kepada keenam siswa untuk memperoleh komentar siswa mengenai bagian LKPD manakah yang sulit untuk dipahami baik dari penggunaan istilah, struktur kalimat, maupun langkah- 
langkah pengerjaan. Berdasarkan komentar keenam siswa, masih terdapat redaksi kalimat yang sulit dipahami pada masalah HOTS sehingga perlu dilakukan beberapa revisi pada redaksi kalimat LKPD. Gambar 16 menunjukkan redaksi kalimat dalam masalah HOTS sebelum direvisi dan Gambar 17 menunjukkan redaksi kalimat dalam masalah HOTS setelah direvisi.

Tabel 4. Hasil angket kepraktisan LKPD.

\begin{tabular}{ccccc}
\hline No & Aspek & Jumlah Item & Rerata & Kriteria \\
\hline 1 & Kemudahan pengunaan & 4 & 3,5 & Sangat Baik \\
2 & Efisiensi & 1 & 3 & Baik \\
3 & Presentasi & 3 & 3,444 & Sangat Baik \\
4 & Bahasa & 1 & 3,167 & Baik \\
5 & Manfaat dalam Pembelajaran & 4 & 3,333 & Baik \\
& Kesimpulan & $\mathbf{1 3}$ & $\mathbf{3 , 2 8 8}$ & Baik \\
\hline
\end{tabular}

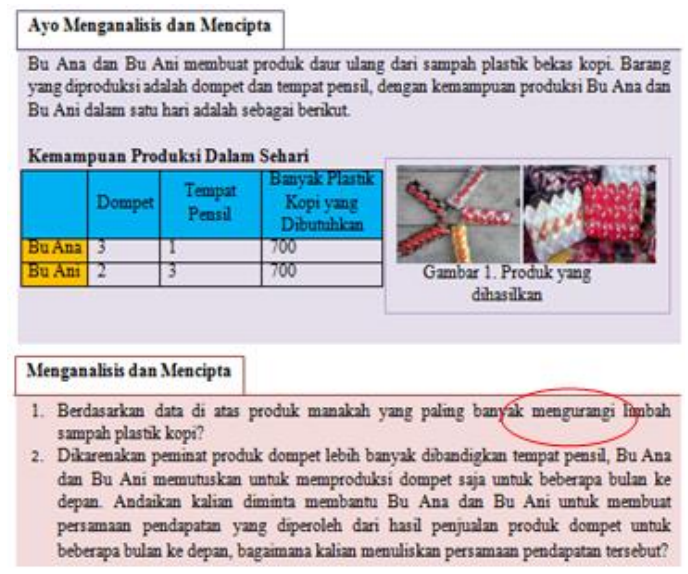

Gambar 16. Redaksi kalimat masalah HOTS sebelum direvisi.

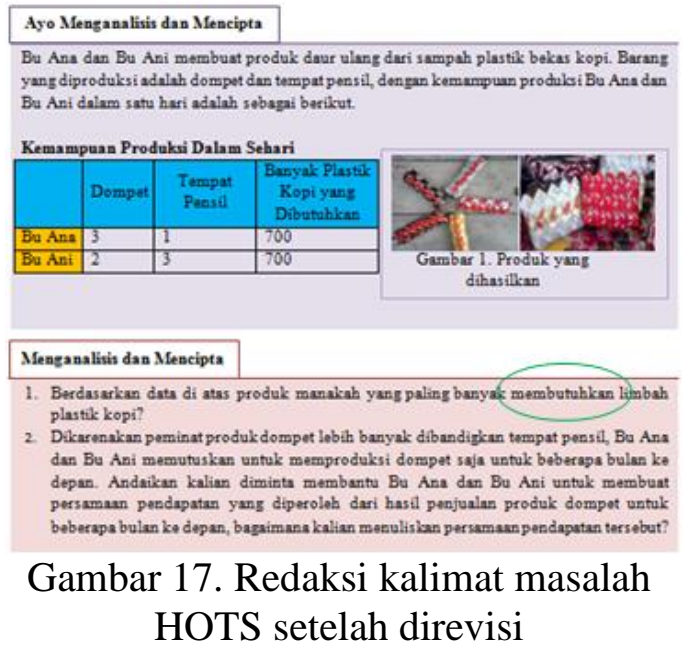

Hasil Prototipe II yang telah direvisi selanjutnya disebut dengan
Prototipe III. Prototipe III merupakan LKPD berbasis HOTS yang telah dinyatakan valid dan praktis melalui serangkaian uji coba dan perbaikan yang telah dilakukan.

Penilaian kevalidan lembar kerja peserta didik berbasis Higher Order Thinking Skills (HOTS) didasarkan pada dua indikator, yaitu indikator ketercapaian lembar kerja peserta didik dan indikator ketercapaian Higher Order Thinking Skills (HOTS). Indikator ketercapaian lembar kerja peserta didik berupa aspek kompetensi, struktur, kontruksi, teknis dan manfaat bagi pembelajaran (Prastowo, 2012). Indikator ketercapian masalah HOTS berupa aspek penggunaan stimulus HOTS dan karakteristik masalah HOTS (Warisdiono, Sutrianto, \& Widana, 2017; Musfiqi \& Jailani, 2014). Dilihat dari aspek penggunaan stimulus HOTS, LKPD menggunakan stimulus yang menarik serta kontekstual guna mendorong siswa untuk membaca. Hal tersebut sesuai dengan ciri masalah HOTS menurut Warisdiono, dkk. (2017), yaitu masalah HOTS pada umumnya menggunakan masalah dikehidupan nyata dan menarik. Dilihat 
dari aspek lainnya, yaitu karakteristik maslaah berbasis HOTS, masalah dalam LKPD menggunakan masalah yang mengukur level kognitif, yaitu menganalisis, mengevaluasi, dan mencipta. Hasil penilaian kevalidan LKPD berbasis HOTS memperoleh rata-rata skor 3,385 dengan kriteria "Baik" sehingga dapat dinyatakan "Valid".

Penilaian kepraktisan didasarkan pada aspek kemudahan penggunaan, efisiensi, presentasi, bahasa dan manfaat dalam pemebelajaran (Ahyan, Zulkardi, \& Darmawijoyo, 2014; Rahmi, Razak, Violita, \& Sumarmin, 2018). Hasil penilaian kepraktisan LKPD berbasis HOTS memperoleh rata-rata skor 3,288 dengan kriteria "Baik", sehingga lembar kerja dapat dinyatakan "Praktis".

LKPD berbasis HOTS dengan menggunakan konteks lingkungan dinilai praktis karena menarik dari segi konten maupun tampilan, dimana masalah HOTS dikaitkan dengan masalah lingkungan agar siswa lebih kritis terhadap masalah lingkungan yang ada disekitar mereka (Habibi, 2014). Pada aspek manfaat dalam pembelajaran, LKPD berbasis HOTS menggunakan konteks lingkungan memperoleh rerata skor 3,333 yang artinya melalui LKPD, siswa terbimbing untuk menumbuhkan keterampilan berpikir tingkat tingginya. LKPD juga memiliki tampilan warna, gambar, dan tulisan yang dapat membantu meningkatkan keingintahuan peserta didik dan meningkatkan pemahaman mereka tentang konsep (Bakry \& Bakar, 2015).

Berdasarkan hasil penilaian kevalidan dan kepraktisan yang telah dilakukan, maka Lembar Kerja Peserta Didik (LKPD) berbasis Higher Order Thinking Skills (HOTS) pada materi Sistem Persamaan Linear Dua Variabel
(SPLDV) menggunakan konteks lingkungan layak digunakan dalam proses belajar mengajar berdasarkan aspek kevalidan dan kepraktisan lembar kerja.

\section{KESIMPULAN DAN SARAN}

Berdasarkan hasil penelitian, lembar kerja peserta didik (LKPD) berbasis higher order thinking skills (HOTS) pada materi Sistem Persamaan Linear Dua Variabel (SPLDV) menggunakan konteks lingkungan yang dikembangkan memenuhi aspek kevalidan dan kepraktisan yang baik sehingga layak digunakan dalam proses pembelajaran matematika. Saran dalam pengembangan produk selanjutnya yaitu, perlu dikembangkan lembar kerja peserta didik berbasis Higher Order Thinking Skills (HOTS) dengan materi yang berbeda dan diharapkan dalam pengembangan produk selanjutnya dapat melakukan pengembangan produk hingga fase penilaian.

\section{DAFTAR PUSTAKA}

Ahyan, S., Zulkardi, \& Darmawijoyo. (2014). Developing Mathematics Problems Based On Pisa Level. IndoMS-JME, Volume 5, No. 1, January 2014, pp. 47-56

Alhassora, N. S. A., Abu, M. S., \& Abdullah, A. H. (2017). Inculcating Higer-Order Thinking Skills In Mathematics: Why Is It So Hard?. Man In India 97(13):51-62 - July 2017.

Alismail, H. A., \& McGuire, P. (2015). $21^{\text {St }}$ Century Standards and Curriculum: Current Research and Practice. Journal of Education and Practice, Vol.6, No.6, 2015. 
Anderson, L.W., dan Krathwohl, D.R. (2010). Kerangka Landasan Untuk Pembelajaran, Pengajaran, dan Asesmen Revisi Taksonomi Pendidikan Bloom. Terjemahan : Agung Prihantoro.Yogyakarta: Pustaka Pelajar.

Arikunto, S. (2010). Prosedur Penelitian Suatu Pendekatan Praktik. Jakarta: Rineka Cipta.

Bakry, \& Bakar, M. N. B. (2015). The Process of Thinking among Junior High School Students in Solving HOTS Question. International Journal of Evaluation and Research in Education (IJERE), Vol.4, No.3, September 2015, pp. 138 145.

Habibi, M. (2014). Environment Education In Mathematics Classroom: As An Effort to Develop The Critical Thinking Skills and for Environmental Sustainability Concerning. Proceeding of International Conference on Research, Implementation and Education of Mathematics and Sciences 2014, Yogyakarta State University, 18-20 May 2014.

Jupri, A., \& Drijvers, P. (2016). Student Difficulties in Mathematizing Word Problems in Algebra. Eurasia Journal of Mathematics, Science \& Technology Education, 2016, 12(9), 24812502.

Liu, X. (2010). Essentials of Science Classroom Assessment. Los Angeles : SAGE.

Musfiqi, S., \& Jailani. (2014). Pengembangan Bahan Ajar
Matematika yang Berorientasi pada Karakter dan Higher Order Thinking Skill (HOTS). PYTHAGORAS: Jurnal Pendidikan Matematika. Volume 9 - Nomor 1, Juni 2014, (45-59).

Norsanty, U. O., \& Chairani, Z. (2016). Pengembangan Lembar Kerja Siswa (LKS) Materi Lingkaran Berbasis Pembelajaran Guided Discovery Untuk Siswa SMP Kelas VIII. Math Didactic: Jurnal Pendidikan Matematika. Vol. 2, No.1, 2016, 12-23.

OECD. (2019). PISA 2018 Insight and Interpretations. $O E C D$ Publishing. Diambil dari https://www.oecd.org/pisa/publi cations/

Plomp, T. (2013). Educational Design Research Part A: An Introduction. SLO Netherlands: Institute for Curriculum Development.

Prastowo, A. (2012). Panduan Kreatif Membuat Bahan Ajar Inovatif. Yogyakarta: Diva Press.

Pratama, G. S., \& Retnawati, H. (2018). Urgency of Higher Order Thinking Skills (HOTS) Content Analysis in Mathematics Textbook. Journal of Physics Conference Series 1097(1):012147.

Rahmi, L., Razak, Violita, \& Sumarmin. (2018). Development of Student's Worksheet with Inquiry Learning Model on Ecological and Environmental Changes for Class $\mathrm{X}$ Senior High School. International Journal of Progressive Sciences 
DOI: https://doi.org/10.24127/ajpm.v9i3.2909

and Technologies (IJPSAT), Vol. 6 No. 2 January 2018, pp. 448-453.(http://ijpsat.ijshtjournals.org)

Syaspasbandah, E. J., Syarifuddin, H., \& Jasrial. (2018). Pengembangan Perangkat Pembelajaran Matematika Berbasis Concept Attainment Mode (CAM) Untuk Peserta Didik Kelas VIII SMP. Journal of Medives. Volume 2, No. 1, 2018, pp. 87-98.

Tanujaya, B. (2016). Development Of An Instrument To Measure Higher Order Thinking Skills In Senior High School Mathematics Instruction. Journal of Education and Practice, Vol.7, No.21, 2016.

Verdina, R., Gani, A., \& Sulastri. (2018). Improving students' higher order thinking skills in thermochemistry concept using worksheets based on 2013 curriculum. J. Phys.: Conf. Ser. 1088012105.
Warisdiono, Sutrianto, \& Widana, I. W. (2017). Modul Penyusunan Soal Higher Order Thinking Skills (HOTS). Jakarta: Direktorat Pembinaan SMA Ditjen Pendidikan Dasar dan Menengah.

Widoyoko, E. P. (2010). Evaluasi Program Pembelajaran Panduan Praktis Bagi Pendidik dan Calon Pendidik. Yogyakarta: Pustaka Pelajar.

Yusri, R., M Nurmi., \& H Delyana. (2018). Development of ICT integrated project based learning student worksheet. Journal of Physics: Conf. Series 1157 (2019) 032127 doi:10.1088/1742$6596 / 1157 / 3 / 032127$ 